\title{
Kiedy i dlaczego w terapii hipotensyjnej wybieram połączenie trójlekowe - perindopril/indapamid/amlodipina?
}

\author{
When and why do I choose triple drug combination \\ - perindopril/indapamide/amlodipine in antihypertensive therapy?
}

\author{
Iwona Gorczyca-Michta ${ }^{1}$, Beata Wożakowska-Kapłon ${ }^{1,2}$ \\ ${ }^{1}$ I Klinika Kardiologii i Elektroterapii Świętokrzyskiego Centrum Kardiologii w Kielcach \\ ${ }^{2}$ Wydział Nauk o Zdrowiu Uniwersytetu Jana Kochanowskiego w Kielcach
}

\begin{abstract}
Streszczenie
U większości chorych z nadciśnieniem tętniczym konieczne jest zastosowanie politerapii w celu osiągnięcia docelowych wartości ciśnienia tętniczego. Preparaty złożone zwiększają przestrzeganie zaleceń lekarskich oraz pozwalają na osiągnięcie docelowych wartości ciśnienia. Połączenie perindoprilu z indapamidem i amlodipiną jest szczególnie wskazane u chorych z nadciśnieniem tętniczym obciążonych metabolicznie ze względu na korzystny, neutralny wpływ na stężenie glukozy i cholesterolu, oraz u chorych z trudnym w kontroli nadciśnieniem tętniczym ze względu na udowodnione skuteczne działanie hipotensyjne.
\end{abstract}

Słowa kluczowe: terapia złożona, preparat trójlekowy, nadciśnienie tętnicze

Folia Cardiologica 2016; 11, 1: 47-56

\section{Nadciśnienie tętnicze - jak często występuje i dlaczego należy je skutecznie leczyć?}

Umieralność z powodu chorób układu sercowo-naczyniowego w Polsce w ostatnich latach istotnie się zmniejszyła, ale nadal stanowi jedną z wyższych w krajach europejskich. W 2013 roku choroby te były przyczyną 46\% wszystkich zgonów w Polsce oraz główną przyczyną zgonów u osób przed 65. rokiem życia [1, 2].

Liczba osób chorujących na nadciśnienie tętnicze w naszym kraju jest większa o 2\% niż 10 lat temu; obecnie choruje około 32\% dorosłych Polaków (10,5 mln osób, w tym 9,5 mln w wieku 18-79 lat i prawie $1 \mathrm{mln}$ osób > 80. rż.). Szacuje się, że $3 \mathrm{mln}$ Polaków nie jest świadomych, że chorują na nadciśnienie tętnicze [3]. Częstość jego występowania zwiększa się z wiekiem. Odsetek chorych na nadciśnienie tętnicze $w$ wieku emerytalnym jest wyższy niż w populacji ogólnej i wynosi 58\%. W badaniu WOBASZ wykazano wyższy niż w badaniu NATPOL III PLUS odsetek chorych na nadciśnienie tętnicze wynoszący 36\% [4].

Nadciśnienie tętnicze jest uznanym czynnikiem ryzyka występowania epizodów niedokrwiennych. W badaniu INTERHEART obejmującym ponad 30 tys. pacjentów zidentyfikowano następujące czynniki ryzyka wystąpienia zawału serca: nadciśnienie tętnicze, dyslipidemię, nikotynizm, otyłość brzuszną, cukrzyce, czynniki psychospołeczne oraz czynniki protekcyjne - umiarkowane spożycie alkoholu, owoców i warzyw. Wykazano, że czynniki te, a wśród nich nadciśnienie tętnicze, odpowiadały za wystąpienie 90\% zawałów serca u mężczyzn oraz 94\% zawałów serca u kobiet [5].

Nadciśnienie tętnicze to najistotniejszy czynnik ryzyka przedwczesnego zgonu na świecie. Obecnie szacuje się, że choruje na nie około 1 mld osób, a większość z nich ma 
nadciśnienie tętnicze 1. stopnia. W badaniu obejmującym 15226 pacjentów z rejestru BPLTTC (Blood Pressure Lowering Treatment Trialists' Collaboration) z nadciśnieniem tętniczym 1. stopnia, bez wywiadu innych chorób układu sercowo-naczyniowego, oceniono wpływ farmakologicznego leczenia hipotensyjnego na ryzyko incydentów sercowo-naczyniowych i zgonu. W grupie chorych objętych badaniem najczęściej stosowanymi lekami hipotensyjnym były inhibitory konwertazy angiotensyny (ACE, angiotensin-converting enzyme) oraz antagoniści wapnia. Chorych tych porównywano pod względem przeżycia oraz częstości występowania incydentów sercowo-naczyniowych z pacjentami z grup kontrolnych, przyjmujących placebo lub pozostających bez leczenia, jak również leczonych metodami niefarmakologicznymi. Średni czas obserwacji wyniósł 4,4 roku. Średnie obniżenie ciśnienia tętniczego (BP, blood pressure) w grupie leczonej wyniosło 3,6/2,4 mm Hg w porównaniu z grupa kontrolną. Stwierdzono, że leczenie farmakologiczne łagodnego nadciśnienia zmniejsza ryzyko sercowo-naczyniowe (iloraz szans [OR, odds ratio] w odniesieniu do wszystkich zdarzeń sercowo-naczyniowych 0,86, 95-proc. przedział ufności [Cl, confidence interval] 0,74-1,01), ryzyko udaru mózgu (OR 0,72, 95\% Cl 0,55-0,94), incydentów wieńcowych (OR 0,91, 95\% Cl 0,74-1,12) oraz niewydolności serca (OR 0,80, 95\% Cl, 0,57-1,12). Farmakoterapia nadciśnienia tętniczego obniżała również ryzyko zgonu (OR 0,78, 95\% Cl 0,67-0,92) [6]. Skuteczne leczenie nadciśnienia tętniczego istotnie poprawia rokowanie, dlatego niezwykle istotne jest dążenie do osiągania docelowych wartości ciśnienia.

\section{Jakie wartości docelowe BP należy osiągnąc u chorych leczonych hipotensyjnie?}

Określenie docelowych wartości BP u chorych leczonych hipotensyjnie zmieniało się w ostatnich latach. Teoria krzywej J, zgodnie z którą niekorzystne rokowanie dotyczy zarówno chorych ze zbyt wysokimi, jak i zbyt niskimi wartościami BP, zmieniła poprzednio obowiązujące zasady leczenia hipotensyjnego, w myśl których celem u chorych obciążonych bardzo wysokim ryzykiem sercowo-naczyniowego było uzyskiwanie wartości BP niższych niż w populacji ogólnej. W obecnie obowiązujących wytycznych Polskiego Towarzystwa Nadciśnienia Tętniczego (PTNT), dotyczących postępowania u chorych z nadciśnieniem tętniczym, zalecana wartość docelowa BP w populacji ogólnej tych chorych wynosi poniżej 140/90 mm Hg [7]. Osiąganie innych wartości docelowych zaleca się w następujących grupach chorych z nadciśnieniem tętniczym:

- u chorych na cukrzyce - docelowa wartość BP poniżej 140/85 mm Hg (wyniki badań ACCORD [Action to control cardiovascular risk in diabetes], HOT [Hypertension Optimal Treatment], INVEST [The International Verapamil SR-Trandolapril Study]);
- u chorych powyżej 80. roku życia - docelowa wartość skurczowego ciśnienia tętniczego (SBP, systolic blood pressure) poniżej 150 mm Hg (wyniki badań HYVET [HYpertension in the Very Elderly Trial]) [7].

Możliwe jednak, że w przyszłości docelowe wartości BP będą niższe. Sugerują to wstępne wyniki badania SPRINT (Systolic Blood Pressure Intervention Trial) prowadzonego przez National Institutes of Health [8]. Od 2009 roku w 100 ośrodkach w Stanach Zjednoczonych i Portoryko włączono do niego 9300 osób powyżej 50. roku życia z nadciśnieniem tętniczym obciążonych co najmniej jednym dodatkowym czynnikiem ryzyka sercowo-naczyniowego lub przewlekłą chorobą nerek, ale bez cukrzycy czy udaru mózgu w wywiadzie. Badanych poddano randomizacji do grupy leczonej standardowo z celem osiągnięcia SBP poniżej $140 \mathrm{~mm} \mathrm{Hg}$ i grupy leczonej intensywnie z celem poniżej $120 \mathrm{~mm} \mathrm{Hg}$. W grupach tych stosowano średnio, odpowiednio, dwa i trzy leki hipotensyjne. Badanie zakończono przedwcześnie ze względu na znaczącą redukcję częstości występowania zdarzeń sercowo-naczyniowych (takich jak zawał serca, udar mózgu i niewydolność serca) o 30\% w grupie chorych, u których osiągano wartości SBP poniżej 120 mm Hg w porównaniu z chorymi, u których dążono do obniżenia wartości SBP poniżej $140 \mathrm{~mm} \mathrm{Hg}$. U chorych intensywniej leczonych hipotensyjnie odnotowano także obniżenie ryzyka zgonu o prawie $25 \%$ w porównaniu z chorymi, u których dążono do uzyskania wartości BP poniżej 140 mm Hg [8].

\section{Dlaczego nie u wszystkich chorych leczonych hipotensyjnie są osiągane docelowe wartości BP?}

Poznanie patomechanizmów nadciśnienia tętniczego oraz rozwój technologii prowadzący do wdrożenia nowoczesnych leków hipotensyjnych potencjalnie pozwala na skuteczną kontrolę nadciśnienia. Jednak odsetek chorych skutecznie leczonych pozostaje niezadowalający. Bardzo niską, jedynie 12-procentową, skuteczność leczenia nadciśnienia tętniczego wykazano w badaniu NATPOL w 2002 roku [9]. Wyniki badania NATPOL 2011 wskazują, że odsetek chorych ze skutecznie leczonym nadciśnieniem w Polsce zwiększył się 2-krotnie i obecnie wynosi 26\% [4]. Bramlage i wsp. [10] w badaniu obejmującym 18652 chorych leczonych z powodu nadciśnienia tętniczego wykazali, że docelowe wartości BP osiągnięto jedynie u 21,2\% chorych. W badaniu tym u 31,2\% osób stosowano monoterapię, a pozostałych poddano leczeniu skojarzonemu. Skuteczność leczenia hipotensyjnego była zróżnicowana terytorialnie. Najwyższy odsetek skutecznie leczonych chorych obserwowano w Ameryce Łacińskiej (30,6\%), a najniższy - wśród chorych na Bliskim Wschodzie (9,6\%) [10]. Przeprowadzona przez NHANES (National Health and Nutrition Examination Survey) analiza dowiodła, że tylko u 53\% osób leczonych 
z powodu nadciśnienia tętniczego osiągnięto docelowe wartości BP [11]. Niższy, wynoszący 48\%, odsetek leczonych skutecznie chorych wykazano w badaniu Framingham Heart Study, a w populacji chorych powyżej 75. roku życia wartości te stwierdzono u 40\% badanych [12]. U chorych leczonych hipotensyjnie, u których nie są osiągane wartości docelowe, często podejrzewa się oporne nadciśnienie tętnicze. Prawdziwie oporne nadciśnienie tętnicze, definiowane jako brak osiągnięcia wartości docelowych, u chorych leczonych hipotensyjnie co najmniej trzema lekami w maksymalnych dawkach i we właściwym skojarzeniu (w tym lek diuretyczny), występuje rzadko. W hiszpańskim badaniu pacjentów leczonych hipotensyjnie, u których skuteczność leczenia nadciśnienia tętniczego badano za pomocą całodobowego monitorowania ciśnienia tętniczego (ABPM, ambulatory blood pressure monitoring), oporne nadciśnienie tętnicze wykazano u 12\% chorych [13]. Najczęstsze przyczyny oporności nadciśnienia przedstawiono na rycinie 1 [14]. Knight i wsp. [15] przeanalizowali czynniki ryzyka niepowodzenia terapii hipotensyjnej. Udowodniono, że najwyższe ryzyko wystąpienia opornego nadciśnienia tętniczego występuje u osób starszych, niedostatecznie poinformowanych o docelowych wartościach BP, osób przyjmujących wiele leków oraz u pacjentów, u których wystąpiły działania niepożądane leku.

Najczęściej przyczyny oporności nadciśnienia tętniczego wynikają ze sposobu jego terapii i są następujące:

- niedostatecznie duże dawki zalecanych leków;

- niewłaściwe połączenia lekowe;

- zbyt rzadkie stosowanie leków diuretycznych;

- zbyt rzadkie stosowanie preparatów złożonych;

- nieprzestrzeganie zasad chronoterapii nadciśnienia tętniczego;

- interakcje lekowe (działania niepożądane wynikające z politerapii lub stosowanie leków osłabiających działanie leków hipotensyjnych).

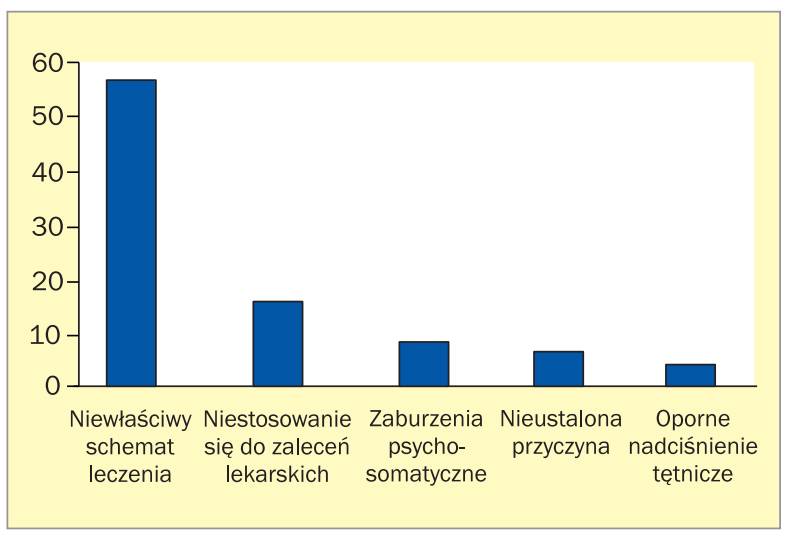

Rycina 1. Przyczyny oporności nadciśnienia tętniczego (na podstawie [13])
Z kolei najważniejszą przyczyną oporności nadciśnienia tętniczego związaną ze zdrowotnymi zachowaniami pacjenta jest nieprzestrzeganie zaleceń lekarskich dotyczących niefarmakologicznych i farmakologicznych zasad leczenia nadciśnienia. Istotne znaczenie mają problemy psychologiczne, na przykład niepokój i lęk napadowy prowadzące do okresowych wzrostów BP.

\section{Czy stosowanie leków złożonych poprawia kontrolę nadciśnienia tętniczego?}

Na podstawie danych z badań epidemiologicznych i klinicznych są opracowywane modele zdrowotne oparte na matematycznej analizie danych. Vontil i wsp. [16] stworzyli model, w którym symulowano wpływ zmian w systemie opieki zdrowotnej na efektywność leczenia u osób z nadciśnieniem tętniczym. Mimo postępów ostatnich lat, właściwy stopień kontroli nadciśnienia tętniczego w populacji Stanów Zjednoczonych jest osiągany u 50-60\% pacjentów. Autorzy prezentowanego badania w oparciu o model matematyczny, posługując się danymi z rejestrów NHANES i badań klinicznych dotyczących skuteczności leków hipotensyjnych, oceniali wpływ częstości wizyt, intensyfikacji leczenia farmakologicznego oraz stopnia przestrzegania zaleceń terapii przez pacjentów na roczne efekty leczenia u osób z niekontrolowanym nadciśnieniem tętniczym. Analizę prowadzono w utworzonej na podstawie rejestrów kohorcie 25000 osób z niekontrolowanym nadciśnieniem tętniczym. Oceniano hipotetyczny efekt następujących scenariuszy poprawy skuteczności leczenia hipotensyjnego o 10\% i 50\% wobec stanu dotychczasowego oraz osiągnięcia idealnego modelu opieki. W idealnym modelu opieki zakładano kontrolne wizyty po 4 tygodniach, zwiększenie intensywności leczenia u 100\% niekontrolowanych pacjentów i optymalne przestrzeganie zaleceń przez pacjentów. W przypadku spełnionych wymienionych warunków osiągnięcie właściwej kontroli nadciśnienia byłoby możliwe u 95\% leczonych po 52 tygodniach stosowanych interwencji. Największy udział w osiągnięciu docelowych wartości BP wykazano w przypadku intensyfikacji leczenia farmakologicznego, następnie właściwej częstości wizyt oraz poprawy przestrzegania zaleceń lekarskich przez pacjentów. Przedstawiony model opieki wskazuje na priorytety w organizowaniu opieki medycznej u chorych z nadciśnieniem tętniczym, a przede wszystkim konieczność intensyfikacji leczenia, przy zwiększonej częstości wizyt [16].

Wyniki randomizowanych badań klinicznych potwierdzają konieczność stosowania więcej niż jednego leku hipotensyjnego w celu osiągnięcia docelowych wartości BP. W grupie chorych z badania HOT średnia liczba leków hipotensyjnych niezbędnych do uzyskania wartości BP poniżej 140/90 mm Hg wynosiła 2,3. W grupie chorych, u których osiągnięto docelowe wartości BP, u 33\% chorych 
stosowano monoterapię, u 45\% - terapię dwoma lekami hipotensyjnymi, a u $22 \%$ badanych konieczne było stosowanie co najmniej trzech leków hipotensyjnych [17]. Sur i wsp. [18] w grupie 674 chorych wykazali, że 2/3 chorych leczonych hipotensyjnie wymagało stosowania przynajmniej dwóch leków w celu osiągnięcia docelowych wartości BP. Jeszcze wyższy odsetek badanych, bo $78 \%$, wymagał stosowania przynajmniej dwóch leków hipotensyjnych w celu osiągnięcia docelowych wartości BP w grupie chorych włączonych do badania ASCOT-BPLA (Anglo-Scandinavian Cardiac Outcomes Trial-Blood Pressure Lowering Arm) [19].

W celu osiągnięcia docelowych wartości BP, w przypadku nieskuteczności monoterapii, można rozważyć zwiększenie dawki dotychczas stosowanego leku lub dołączyć lek o innym mechanizmie działania. Zwiększenie dawki leku i utrzymanie monoterapii istotnie zwiększa ryzyko wystąpienia działań niepożądanych. Szacuje się, że podwojenie dawki leku hipotensyjnego zwiększa efekt hipotensyjny o 30\%, a efekt toksyczny - o blisko 100\%. By uzyskać 2-krotnie silniejsze działanie hipotensyjne leku, należy zastosować 10-krotnie większą dawkę tego leku, co 8-krotnie zwiększa jego efekt toksyczny [20]. Zatem optymalnym rozwiązaniem u chorego leczonego nieskutecznie jednym lekiem hipotensyjnym jest dołączenie leku hipotensyjnego o innym mechanizmie działania, a nie zwiększanie dawki dotychczas stosowanego leku.

Podstawą optymalnej terapii hipotensyjnej jest właściwe skojarzenie leków, ale również przestrzeganie zaleceń lekarskich. Przestrzeganie zaleceń dotyczących leczenia określane jest wskaźnikami takimi jak adherence przestrzeganie zaleceń lekarskich wyrażone odsetkiem przyjmowanych dawek leku oraz persistence - wytrwałość w stosowaniu terapii, dotycząca czasu w jakim lek jest przyjmowany. Można to osiągnąc między innymi poprzez podawanie pojedynczej tabletki zawierającej w sobie dwa lub trzy składniki o różnych mechanizmach działania hipotensyjnego. Stosowanie leków złożonych znacznie poprawia współpracę lekarza z chorym.

W badaniu Saito i wsp. [21] oceniano chorych uczestniczących w trzech badaniach kohortowych dotyczących stosowania antagonisty wapnia - azelnidipiny, olmesartanu oraz preparatu złożonego zawierającego oba te leki. Badaniem objęto dwie grupy chorych po 1074 osób poddanych terapii skojarzonej (CT, combined treatment) lub leczeniu preparatem złożonym (FDC, fixed-dose combination). Po 12 tygodniach terapii wskaźniki przerwania leczenia (non-persistence) wynosiły 10,1\% i 6,7\%, odpowiednio, w grupach poddanych CT i leczeniu FDC ( $p<0,0074$ ). Wartości BP były statystycznie niższe w grupie leczonej FDC niż w grupie poddanej CT i wynosiły, odpowiednio, 136,8/75,9 mm Hg oraz 140,8/78,6 mm Hg. Adherence określano za pomocą wskaźnika PDC (proportion of days covered), czyli ilorazu liczby dni, na które pacjent wykupił leki, i liczby dni obserwacji. Wartość tego wskaźnika przekraczająca 0,8 oznaczała stosowanie się do zaleceń. Odsetki dobrego wskaźnika adherence były znacząco wyższe w grupie leczonej FDC niż w grupie poddanej CT po 3 miesiącach (78\% v. 71\%), po 6 miesiącach $(69 \%$ v. 59,5\%) i po 12 miesiącach terapii (58\% v. 46,5\%) [21].

Angeloni i wsp. [22] porównali skuteczność hipotensyjną leków dwuskładnikowych u chorych z dotychczas nieleczonym nadciśnieniem tętniczym. Chorych leczono jednym z następujących połączeń lekowych: enalapril z lerkanidipina, ramipril z hydrochlorotiazydem, enalapril z hydrochlorotiazydem, olmesartan z hydrochlorotiazydem, telmisartan z hydrochlorotiazydem, perindopril z amlodipiną. Wyjściowe wartości SBP i ciśnienia rozkurczowego (DBP, diastolic blood pressure) wynosiły, odpowiednio, $157 \mathrm{~mm} \mathrm{Hg}$ i $95 \mathrm{~mm} \mathrm{Hg}$. Po 4 tygodniach leczenia cele terapii ( $\leq 140 / 90 \mathrm{~mm} \mathrm{Hg}$ i $\leq 130 / 80 \mathrm{~mm} \mathrm{Hg} \mathrm{w}$ grupach wysokiego ryzyka) osiągnięto u $73,2 \%$ badanych, a objawy niepożądane odnotowano u $2,8 \%$. W grupie chorych z dobrze kontrolowanym ciśnieniem $90 \%$ badanych utrzymało osiągnięte początkowo jego docelowe wartości przez okres całego badania, czyli przez 6 miesięcy [22]. W badaniu tym oceniono także podgrupy wysokiego ryzyka. Najwyższą skuteczność leczenia hipotensyjnego u chorych na cukrzycę stwierdzono w odniesieniu do połączenia inhibitora ACE z antagonistą wapnia. Docelowe wartości $\mathrm{BP}(\leq 130 / 80 \mathrm{~mm} \mathrm{Hg}$ ) osiągnięto u $51-52 \%$ chorych na cukrzycę leczonych perindoprilem i amlodipiną oraz u 46,8-49\% chorych otrzymujących preparat złożony zawierający diuretyk tiazydowy [22].

Odsetek chorych przestrzegających zaleceń lekarskich jest tym wyższy, im rzadsze jest zalecone dawkowanie leków w ciągu doby. Udowodniono to już w latach 80 . ubiegłego wieku w opracowaniu obejmującym dane z 33 badań, w którym wykazano, że odsetek współpracujących chorych wynosił $42 \pm 5 \%$ w przypadku osób stosujących leki 4 razy/ /dobę oraz $73 \pm 6 \%$ w przypadku osób przyjmujących leki raz na dobę [23]. Stosowanie leków złożonych zmniejsza liczbę przyjmowanych leków oraz ogranicza ich stosowanie do jednorazowego podania. Według wytycznych European Society of Hypertension/European Society of Cardiology (ESH/ESC) z 2013 roku [24] oraz wytycznych PTNT [25] w terapii dwoma lekami hipotensyjnymi zaleca się wybór spośród następujących połączeń:

- inhibitor ACE + diuretyk tiazydowy/tiazydopodobny;

- inhibitor ACE + antagonista wapnia;

- antagonista wapnia + diuretyk tiazydowy/tiazydopodobny;

- antagonista wapnia + beta-adrenolityk;

- inhibitor ACE + beta-adrenolityk;

- sartan + diuretyk tiazydowy/tiazydopodobny;

- sartan + antagonista wapnia (ryc. 2).

$\mathrm{U}$ chorych z umiarkowanym lub ciężkim nadciśnieniem tętniczym lub u chorych, u których należy obniżyć wartości SBP o $20 \mathrm{~mm} \mathrm{Hg}$, zaleca się rozpoczynanie leczenia 


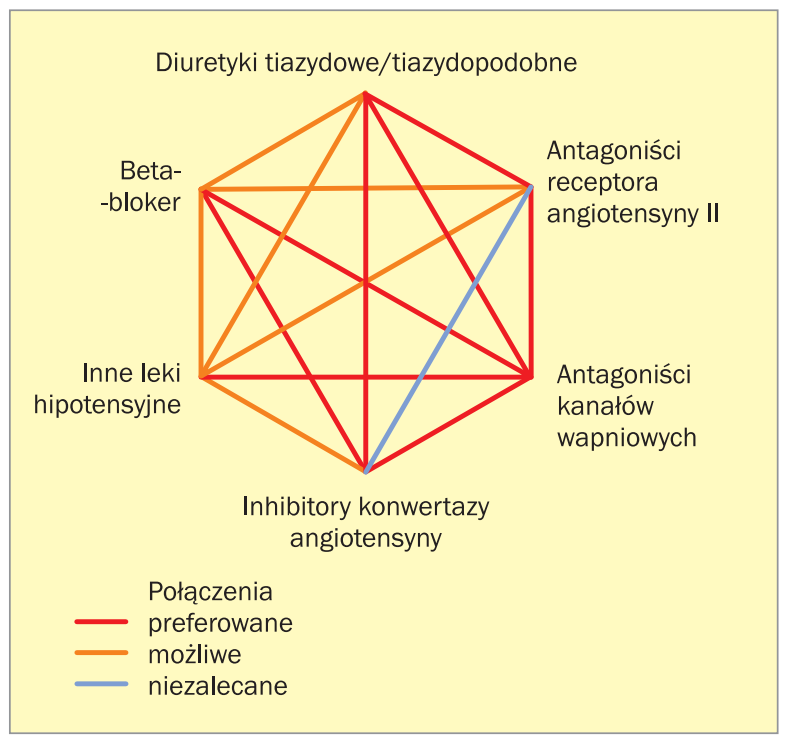

Rycina 2. Preferowane połączenia lekowe u chorych wymagających politerapii nadciśnienia tętniczego (na podstawie [25])

hipotensyjnego od dwóch leków, a preferuje leczenie preparatem złożonym [25]. U 1/3 chorych w celu uzyskania dostatecznej kontroli BP konieczne jest zastosowanie co najmniej trzech leków hipotensyjnych. U chorych z niepowikłanym nadciśnieniem tętniczym preferowanymi wyborami są lek blokujący układ renina-angiotensyna-aldosteron (RAA), diuretyk tiazydowy/tiazydopochodny oraz antagonista wapnia [25]. W wymienionym skojarzeniu trójlekowym amlodipina oraz działający moczopędnie indapamid pośredniczą w natriurezie i stymulują aktywność reniny, natomiast inhibitor ACE hamuje układ RAA. Zgodnie z aktualną wiedzą na temat patofizjologii nadciśnienia tętniczego oczekuje się, że jednoczesne działanie ukierunkowane na wspomniane szklaki patofizjologiczne pozwoli przywrócić równowagę między aktywnością reniny i stężeniem sodu, co pozwoli na dobrą kontrolę BP.

\section{Perindopril, indapamid i amlodipina w złożonej terapii hipotensyjnej — dla kogo?}

Perindopril jest inhibitorem ACE o udowodnionym działaniu hipotensyjnym. Jego aktywny metabolit charakteryzuje się długim okresem półtrwania (17 h) oraz licznymi właściwościami plejotropowymi. W metaanalizie Savarese i wsp. [26] obejmującej 108233 pacjentów (26 badań) wykazano, że inhibitory ACE znamiennie, o 15\%, obniżały ryzyko wystąpienia pierwszorzędowego punktu końcowego (zgon z przyczyn sercowo-naczyniowych, zawał serca, udar mózgu) oraz zmniejszały o 8\% ryzyko śmiertelności z wszystkich przyczyn. Wśród inhibitorów ACE perindopril był jedynym lekiem znamiennie zmniejszającym częstość występowania pierwszorzędowego punktu końcowego oraz zdarzeń sercowo-naczyniowych (zawał serca i niewydolność serca)
[26]. Perindopril charakteryzuje się większą specyficznością wiązania z tkankową frakcją ACE („tkankowy” inhibitor ACE) niż tradycyjne hydrofilne inhibitory ACE, takie jak enalapril i kaptopril, które silnie się wiążą z frakcją osoczową enzymu („osoczowe” inhibitory ACE). Wiadomo, że leki z grupy tkankowych inhibitorów ACE charakteryzują się korzystniejszymi właściwościami farmakokinetycznymi głównie w zakresie długości okresu efektywnego działania hipotensyjnego, czyli wskaźnika T/P (through-to-peak ratio), jak również większą zdolnością selektywnego wiązania bradykininy w stosunku do inhibitorów osoczowych, co może mieć znaczenie kliniczne [27]. Ta biochemiczna właściwość perindoprilu może tłumaczyć jego korzystne działanie w prewencji zdarzeń sercowo-naczyniowych.

Indapamid jest diuretykiem tiazydopodobnym działającym w korowym odcinku części wstępującej pętli nefronu. Osłabia także odpowiedź na różne czynniki naczynioskurczowe, zwiększa podatność tętnic, zmniejsza całkowity i tętniczkowy opor naczyniowy, wspomaga wytwarzanie prostacykliny i nasila działanie naczyniorozszerzające bradykininy. Ponadto lek ten wykazuje bezpośrednie działanie naczyniorozkurczowe na naczynia krwionośne, ponieważ zmniejsza opor obwodowy. W obecnie obowiązujących wytycznych PTNT [25] zaleca się wybór leków tiazydopodobnych zamiast diuretyków tiazydowych ze względu na ich korzystniejszy profil metaboliczny. Ponadto w takich badaniach, jak ALLHAT (Antihypertensive and Lipid Lowering Treatment to Prevent Heart Attack Trial) [28], ADVANCE (Action in Diabetes and Vascular Disease) [29] i HYVET (HYpertension In The Very Elderly Trial) [30], potwierdzono skuteczność leków tiazydopodobnych w prewencji zdarzeń sercowo-naczyniowych. Nie wykazano wpływu hydrochlorotiazydu na obniżenie ryzyka występowania zdarzeń sercowo-naczyniowych [31, 32].

Amlodipina, w przeciwieństwie do innych pochodnych dihydropirydyny, występuje w postaci zjonizowanej, co decyduje o jej unikatowych właściwościach farmakologicznych. Wysoki stopień jonizacji ogranicza przechodzenie amlodipiny przez lipidy błony komórkowej, co opóźnia działanie biologiczne leku. Istotnie różni to amlodipinę od niezjonizowanych przedstawicieli tej grupy leków, takich jak felodipina i nitrendipina. Amlodipina hamuje także proliferację komórek mięśni gładkich naczyń, która jest kluczowym elementem patogenezy miażdżycy oraz obniża ciśnienie centralne w aorcie, co może wyjaśniać jej długoterminowy korzystny wpływ ograniczający występowanie zdarzeń sercowo-naczyniowych.

Skuteczność terapii hipotensyjnej z zastosowaniem leczenia złożonego perindoprilem, indapamidem i amlodipiną udowodniono w badaniu PAINT [33]. Celem pierwszorzędowym badania była ocena skuteczności hipotensyjnej kombinacji perindoprilu, indapamidu i amlodipiny u pacjentów z nieskutecznie leczonym nadciśnieniem tętniczym. Badaniem objęto 7357 chorych z nadciśnieniem tętniczym 


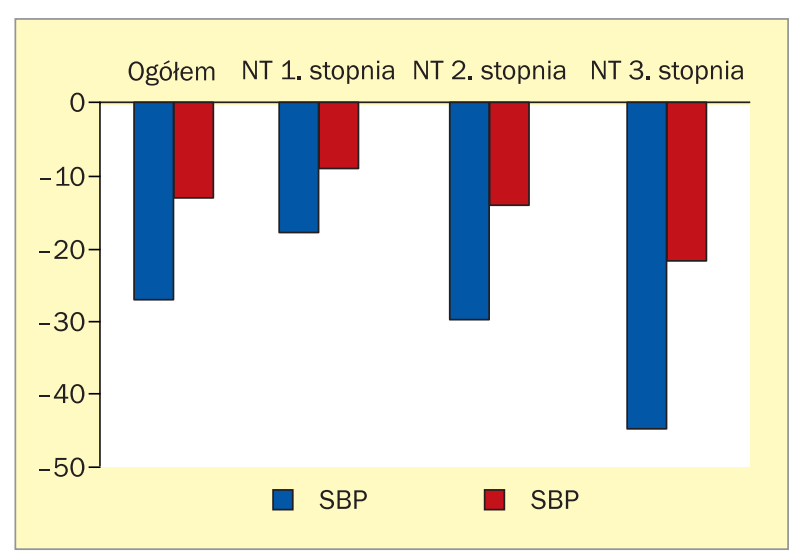

Rycina 3. Redukcja wartości ciśnienia tętniczego u chorych leczonych lekiem złożonym perindopril/amlodypina/indapamid (na podstawie [33]); NT - nadciśnienie tętnicze; SBP (systolic blood pressure) - skurczowe ciśnienie tętnicze; DBP (diastolic blood pressure) - rozkurczowe ciśnienie tętnicze

o średnim czasie trwania 10,3 $\pm 8,4$ roku. Średni wiek uczestników badania wynosił $61,5 \pm 12$ lat. U 1/4 chorych rozpoznano cukrzycę lub chorobę niedokrwienną serca. Średnia wartość gabinetowego BP wynosiła 158,5 \pm $\pm 13,1 / 92,9 \pm 8,8 \mathrm{~mm}$ Hg. Badanie trwało 4 miesiące i było realizowane $\mathrm{w}$ wielu ośrodkach metodą otwartej próby. U pacjentów leczonych nieskutecznie różnymi lekami włączano do terapii preparat złożony perindopril/indapamid/ /amlodipina w jednej z następujących dawek: $5 / 1,5 / 5 \mathrm{mg}$, 5/1,5/10 mg, 10/2,5/5 mg lub 10/2,5/10 mg. Po 4 miesiącach leczenia obserwowano obniżenie wartości SBP o $27 \mathrm{~mm} \mathrm{Hg}$, co pozwoliło na osiągnięcie średniej wartości BP wynoszącej 131,4/79,8 mm Hg. Zaobserwowano, że redukcja wartości BP była tym większa, im wyższe były wartości wyjściowe (ryc. 3). Skurczowe ciśnienie tętnicze u chorych leczonych lekiem trójskładnikowym było istotnie obniżone niezależnie od stosowanej uprzednio terapii. Obniżenie wartości SBP u chorych leczonych następującymi połączeniami lekowymi wynosiło, odpowiednio: inhibitorem ACE oraz antagonistą wapnia $-25,3 \mathrm{~mm} \mathrm{Hg}$, inhibitorem ACE oraz hydrochlorotiazydem $-26,1 \mathrm{~mm} \mathrm{Hg}$, sartanem oraz antagonistą wapnia $-27,4 \mathrm{~mm} \mathrm{Hg}$, sartanem oraz hydrochlorotiazydem - 27,5 mm Hg. Zdarzenia niepożądane, takie jak obrzęki obwodowe, kaszel i ból głowy, obserwowano rzadko, a stężenie potasu utrzymało się na stabilnym poziomie. W subanalizie badania ADVANCE wykazano, że w grupie leczonej perindoprilem z indapamidem i jednocześnie, niezależnie od protokołu, antagonistą wapnia (najczęściej była to amlodipina) redukcja ryzyka zgonów sercowo-naczyniowych była 2-krotnie większa niż pod wpływem perindoprilu z indapamidem $w$ całej populacji badania ADVANCE [34].

W badaniu PIANIST (Perindopril-Indapamide plus AmlodipiNe in high rlSk hyperTensive patients) oceniano

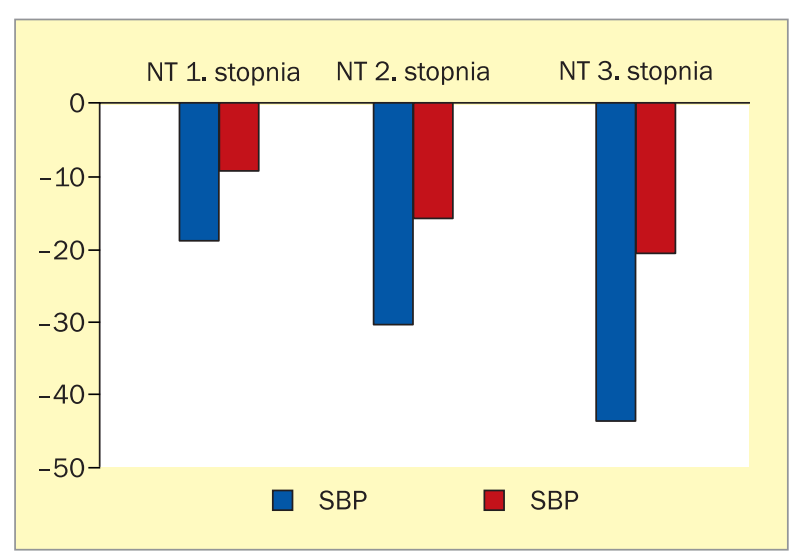

Rycina 4. Redukcja wartości ciśnienia tętniczego w pomiarach gabinetowych u chorych leczonych lekiem złożonym perindopril/amlodipina/indapamid (na podstawie [34]); NT - nadciśnienie tętnicze; SBP (systolic blood pressure) - skurczowe ciśnienie tętnicze; DBP (diastolic blood pressure) - rozkurczowe ciśnienie tętnicze

skuteczność połączenia trójlekowego perindoprilu, indapamidu i amlodipiny u chorych z trudno poddającym się kontroli nadciśnieniem tętniczym. Średni czas trwania nadciśnienia w badanej grupie wynosił $11,9 \pm 8,2$ roku. U 1/3 pacjentów stwierdzono chorobę niedokrwienną serca lub cukrzycę, a połowa badanych miała nadciśnienie tętnicze 2. stopnia. Średnia wartość BP mierzonego w gabinecie lekarskim wynosiła 160,5 \pm 13,3/93,8 \pm $\pm 8,7 \mathrm{~mm} \mathrm{Hg}$. Populacja chorych w badaniu PIANIST była obciążona wyższym ryzykiem sercowo-naczyniowym niż chorzy w badaniu PAINT. Badanie także trwało 4 miesiące, a chorzy otrzymywali perindopril, indapamid i amlodipinę w dawkach 10/2,5/5 mg lub 10/2,5/10 mg. W badaniu PAINT część chorych otrzymywała lek złożony z mniejszą dawką perindoprilu (5 mg), której nie stosowano $u$ chorych $w$ badaniu PIANIST. Po 4 miesiącach leczenia preparatem złożonym perindopril/indapamid/amlodipina uzyskano obniżenie wartości SBP o $28,3 \mathrm{~mm} \mathrm{Hg}$ oraz DBP o 13,8 mm Hg. Średnia wartość BP w pomiarach gabinetowych wynosiła 132,2/80 mm Hg. Zmiany wartości BP mierzonego w gabinecie lekarskim u chorych objętych badaniem PIANIST przedstawiono na rycinie 4. Docelowe wartości BP uzyskano u $72 \%$ wszystkich badanych, u $81 \%$ chorych leczonych uprzednio inhibitorem ACE i hydrochlorotiazydem oraz u $91 \%$ chorych otrzymujących przed włączeniem do badania sartan i hydrochlorotiazyd [35]. W ABPM u chorych leczonych preparatem trójlekowym docelowe wartości BP w ciągu całej doby (< 130/80 mm Hg) uzyskano u 72,1\% chorych, w ciągu dnia (< 135/85 mm Hg) - u 79,8\% badanych, a w ciagu nocy (< 120/70 mm Hg) - u 51\% pacjentów [35]. Mimo trudności z uzyskaniem docelowych wartości BP u chorych z grupy wysokiego ryzyka, istotne obniżenie wartości BP zaobserwowano już po miesiącu od zmiany 
terapii na perindopril/indapamid/amlodipinę. W związku z wykazaniem predykcyjnej wartości odsetka odpowiedzi po miesiącu leczenia w odniesieniu do występowania odległych zdarzeń sercowo-naczyniowych i przeżywalności terapia trójlekowa może przynosić istotne korzyści długoterminowe. Ponadto istotna redukcja zmienności wartości BP w ABPM u chorych leczonych preparatem trójlekowym również sugeruje prawdopodobne długoterminowe ograniczenie chorobowości i śmiertelności. Wynika to z faktu, że wahania wartości BP w ciągu dnia istotnie zwiększają ryzyko wystąpienia subklinicznych uszkodzeń narządowych i zwiększają ryzyko sercowo-naczyniowe.

Synergia między mechanizmami działania perindoprilu, indapamidu i amlodipiny, poza istotnym obniżeniem BP, prowadzi do poprawy tolerancji leczenia w porównaniu ze stosowaniem wymienionych substancji osobno. Inhibitory ACE obniżają ryzyko obrzęku powodowanego przez leki z grupy antagonistów wapnia, amlodipina może zmniejszać ryzyko wystąpienia kaszlu indukowanego przez inhibitory ACE, a indapamid, dzięki swojej neutralności, poprawia profil metaboliczny po zastosowaniu hydrochlorotiazydu lub leku beta-adrenolitycznego [36, 37]. Dobra tolerancja leczenia istotnie poprawia poziom współpracy pacjenta z lekarzem, ponieważ - leczenia zaprzestaje niski odsetek chorych.

Terapia skojarzona perindoprilem, indapamidem i amlodipiną w postaci leku złożonego jest zalecana w niepowikłanym nadciśnieniu tętniczym 2. i 3. stopnia, zwłaszcza u chorych aktywnych zawodowo oraz tych, którzy mogą mieć trudności z przestrzeganiem zaleceń, a także u chorych po nieskutecznej terapii kilkoma lekami hipotensyjnymi w skojarzeniu. Połączenie takie jest również wskazane u chorych z nadciśnieniem tętniczym obciążonych wysokim ryzykiem sercowo-naczyniowym, chorobą niedokrwienną, miażdżycą tętnic obwodowych, cukrzycą, zespołem metabolicznym, otyłością, małą aktywnością fizyczną, dyslipidemią, u chorych po udarze mózgu i z utrzymującymi się wysokimi wartościami BP mimo terapii skojarzonej. To nowe trójlekowe połączenie charakteryzuje się całodobowym działaniem wszystkich trzech leków z dobrym uzupełnianiem się farmakokinetyki w zakresie czasu osiągania maksymalnego stężenia poszczególnych składowych preparatu złożonego z perindoprilu, indapamidu i amlodipiny, co prowadzi do zrównoważonego działania hipotensyjnego bez niebezpieczeństwa hipotonii.

\section{Zastosowanie preparatu złożonego perindopril/indapamid/amlodipina $\mathrm{w}$ praktyce klinicznej - opis przypadku klinicznego}

Charakterystyka pacjenta:

- mężczyzna, 69 lat;

- leczony w poradni nadciśnienia tętniczego, skierowany przez lekarza rodzinnego z powodu nieskuteczności leczenia nadciśnienia;

- nadciśnienie tętnicze od 20 lat, obecnie leczone następująco: ramipril $10 \mathrm{mg}$ rano, lerkanidipina $20 \mathrm{mg}$ w południe, ne biwolol $5 \mathrm{mg}$ rano, hydrochlorotiazyd $25 \mathrm{mg} \mathrm{raz} /$ dobę rano, spironolakton $25 \mathrm{mg}$ raz/dobe w południe;

- choroba niedokrwienna serca: stabilna dławica piersiowa, stan po zawale serca przed laty i przezskórnej interwencji wieńcowej z implantacją stentu metalowego w gałęzi przedniej zstępującej lewej tętnicy wieńcowej;

- przejściowy epizod niedokrwienny mózgu pół roku temu;

- otyłość (wskaźnik masy ciała [BMI, body mass index] $33 \mathrm{~kg} / \mathrm{m}^{2}$ ), nikotynizm, hipercholesterolemia mieszana, cukrzyca typu 2;

- w gabinetowych pomiarach BP maksymalne wartości 160/105 mm Hg;

- w domowych pomiarach BP: w godzinach porannych - zwykle prawidłowe wartości BP, w godzinach popołudniowych - wartości BP maksymalnie 156/90 mm Hg;

- badanie elektrokardiograficzne - amplitudowe cechy przerostu mięśnia lewej komory, załamki R w odprowadzeniu V6 wynoszące $30 \mathrm{~mm}$;

- badanie ultrasonograficzne (USG) tętnic szyjnych metodą Dopplera: grubość kompleksu intima-media (IMT, intima-media thickness) $0,78 \mathrm{~mm}$, bez zmian miażdżycowych;

- prędkość fali tętna (PWV, pulse wave velocity) - 7,5 m/s (wartość prawidłowa);

- wskazanie do wykonania ABPM - ocena skuteczności leczenia hipotensyjnego.

Na rycinie 5 przedstawiono wykres wartości BP w ciągu całej doby.

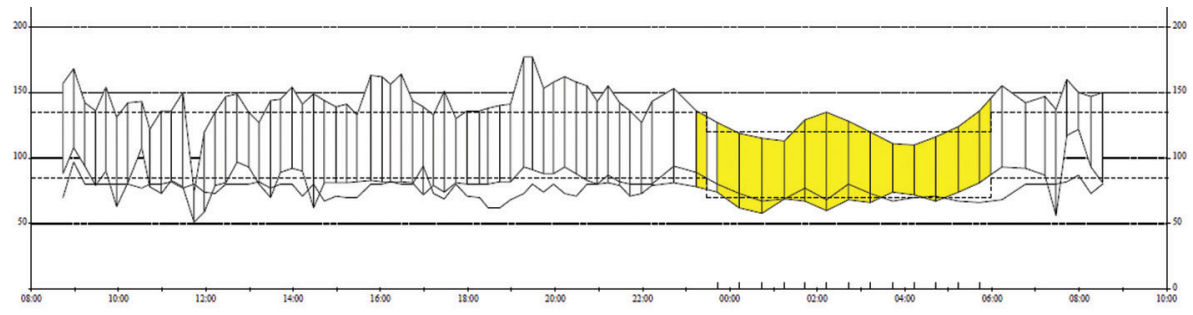

Rycina 5. Wykres wartości ciśnienia tętniczego w ciągu całej doby (aparat GE Tonoport V) (przedrukowano za zgodą z: Gorczyca-Michta I., Wożakowska-Kapłon B. Całodobowe monitorowanie ciśnienia tętniczego w praktyce klinicznej. Via Medica, Gdańsk 2015: 61) 
Tabela 1. Wynik całodobowego monitorowania ciśnienia tętniczego (przedrukowano za zgodą z: Gorczyca-Michta I., Wożakowska-Kapłon B. Całodobowe monitorowanie ciśnienia tętniczego w praktyce klinicznej. Via Medica, Gdańsk 2015: 62)

\begin{tabular}{|c|c|c|c|c|c|c|c|}
\hline \multicolumn{8}{|c|}{ Czas trwania monitorowania: 23 godz. 50 min } \\
\hline \multicolumn{4}{|c|}{ Okres snu: $23.30-06.00$} & \multicolumn{4}{|c|}{ Godzina wstania z łóżka: brak danych } \\
\hline \multicolumn{8}{|c|}{ Liczba pomiarów poddawanych interpretacji: 78 z 78 (100\%) } \\
\hline \multicolumn{8}{|c|}{ Liczba interpretowanych pomiarów (łącznie/dzień/noc): 78/65/13 } \\
\hline & & SBP & DBP & & & SBP & DBP \\
\hline $\begin{array}{l}\text { Średnia war- } \\
\text { tość BP } \\
\text { [mm Hg] }\end{array}$ & $\begin{array}{l}\text { Cała doba } \\
\text { Czuwanie } \\
\text { Sen }\end{array}$ & $\begin{array}{l}140,6 \\
144,4 \\
121,7\end{array}$ & $\begin{array}{l}80,6 \\
83 \\
68,5\end{array}$ & $\begin{array}{l}\text { Minimalna wartość BP } \\
{[\mathrm{mm} \mathrm{Hg}]}\end{array}$ & $\begin{array}{l}\text { Czuwanie } \\
\text { Sen }\end{array}$ & $\begin{array}{l}74 \\
100\end{array}$ & $\begin{array}{l}51 \\
58\end{array}$ \\
\hline $\begin{array}{l}\text { Ładunek BP } \\
\text { (\%) }\end{array}$ & $\begin{array}{l}\text { Czuwanie } \\
\text { Sen }\end{array}$ & $\begin{array}{l}83 \\
33,8\end{array}$ & $\begin{array}{l}46,1 \\
38,4\end{array}$ & $\begin{array}{l}\text { Maksymalna wartość BP } \\
\text { [mm Hg] }\end{array}$ & $\begin{array}{l}\text { Czuwanie } \\
\text { Sen }\end{array}$ & $\begin{array}{l}177 \\
136\end{array}$ & $\begin{array}{l}122 \\
81\end{array}$ \\
\hline \multirow[t]{2}{*}{$\begin{array}{l}\text { Dobowy profil } \\
\text { BP }\end{array}$} & $\begin{array}{l}\text { Nocny spadek BP (\%) } \\
\text { BP noc/BP dzień }\end{array}$ & $\begin{array}{l}-15,7 \\
0,84\end{array}$ & $\begin{array}{l}-17,3 \\
0,83\end{array}$ & \multirow[t]{2}{*}{$\begin{array}{l}\text { Zmienność BP } \\
{[S D]}\end{array}$} & \multirow[t]{2}{*}{$\begin{array}{l}\text { Czuwanie } \\
\text { Sen }\end{array}$} & \multirow[t]{2}{*}{$\begin{array}{l}14,7 \\
8,4\end{array}$} & \multirow[t]{2}{*}{$\begin{array}{l}12 \\
6,2\end{array}$} \\
\hline & Poranny wzrost BP [mm Hg] & 32,4 & 25,7 & & & & \\
\hline
\end{tabular}

SBP (systolic blood pressure) - skurczowe ciśnienie tętnicze; DBP (diastolic blood pressure) - rozkurczowe ciśnienie tętnicze; BP (blood pressure) - ciśnienie tętnicze; SD (standard deviation) - odchylenie standardowe

W całodobowym monitorowaniu BP stwierdzono:

- średnie wartości BP:

- z całej doby: SBP nieprawidłowe, DBP nieprawidłowe,

- z okresu czuwania: SBP nieprawidłowe, DBP prawidłowe,

- z okresu snu: SBP nieprawidłowe, DBP prawidłowe;

- ładunek BP:

- z okresu czuwania: SBP nieprawidłowy, DBP nieprawidłowy,

- z okresu snu: SBP nieprawidłowy, DBP nieprawidłowy;

- zmienność BP:

- z okresu czuwania: SBP prawidłowa, DBP prawidłowa,

- z okresu snu: SBP prawidłowa, DBP prawidłowa;

- nocny spadek BP:

- SBP prawidłowy,

- DBP prawidłowy;

- dobowy profil BP dipper;

- poranny wzrost BP:

- SBP prawidłowy;

- DBP graniczny (tab. 1).

Na podstawie wyniku pomiarów domowych, gabinetowych BP oraz ABPM następująco zmodyfikowano leczenie hipotensyjne:

- nebiwolol 5 mg rano;

- perindopril/indapamid/amlodipina 10/2,5/10 mg rano.

W trakcie kontrolnej wizyty w poradni nadciśnienia tętniczego 6 tygodni po modyfikacji leczenia obserwowano normalizację wartości BP w pomiarach domowych - maksymalnie wynosiły 134/80 mm Hg, a w pomiarach gabi- netowych nie przekraczały 139/88 mm Hg. Ze względu na skuteczność terapii hipotensyjnej oraz jej dobrą tolerancję utrzymano zaleconą farmakoterapię. U prezentowanego chorego, wymagającego wielolekowej terapii nadciśnienia tętniczego, przy współistniejących schorzeniach sercowo-naczyniowych i metabolicznych, należy zwrócić uwagę na wybór odpowiednich preparatów w obrębie klas leków. W obecnie obowiązujących wytycznych PTNT podkreśla się różnice między poszczególnymi preparatami w danej klasie leków. Należy zwrócić uwagę, że u opisanego chorego wybrano perindopril z grupy inhibitorów ACE jako lek zalecany u pacjentów z chorobą niedokrwienną serca oraz u chorych ze schorzeniami metabolicznymi [25].

\section{Podsumowanie}

Wyniki badań PAINT i PIANIST potwierdzają skuteczność i bezpieczeństwo preparatu złożonego zawierającego perindopril, indapamid i amlodipinę w terapii hipotensyjnej. Chorzy w wymienionych badaniach byli obciążeni wysokim lub bardzo wysokim ryzykiem sercowo-naczyniowym i głównie dla takich pacjentów opracowano połączenie trójlekowe w terapii hipotensyjnej. Choć przedstawionych badań nie zaplanowano w celu oceny długoterminowych punktów końcowych, to jednak wiele danych klinicznych dotyczących opisywanych leków, stosowanych w monoterapii lub terapii dwulekowej, sugerują, że wpływ terapii trójlekowej na rokowanie długoterminowe może być znamienny.

\section{Konflikt interesów}

BWK - honoraria za wykłady: Servier. 


\section{Abstract}

Most of the patients with hypertension require combined therapy in order to achieve target blood pressure. Antihypertensive agents should improve compliance with medical recommendations and allow achieving therapeutic goals. The combination of perindopril with indapamide and amlodipine is particularly recommended in population of hypertensive patients with metabolic complications because of favourable, neutral effect on blood glucose and cholesterol level. This combination has proven hypotensive effect in group of patients with difficult-to-control hypertension.

Key words: combination therapy, triple-drug combination, hypertension

Folia Cardiologica 2016; 11, 1: 47-56

\section{Piśmiennictwo}

1. Zatoński W. (red.). Closing the health gap in European Union. Cancer Epidemiology and Prevention Division. Maria Skłodowska-Curie Memorial Cancer Center and Institute of Oncology, Warsaw 2008.

2. Roczniki branżowe. Rocznik Demograficzny. Główny Urząd Statystyczny, Warszawa 2015. Dostępne na: http://stat.gov.pl/en/topics/ /statistical-yearbooks/. Data dostępu: 23.01.2016.

3. http://gumed.edu.pl. Data dostępu: 22.02.2016.

4. Tykarski A., Posadzy-Małaczyńska A., Wyrzykowski B. i wsp. Rozpowszechnienie nadciśnienia tętniczego oraz skuteczność jego leczenia u dorosłych mieszkańców naszego kraju. Wyniki programu WOBASZ. Kardiol. Pol. 2005; 63 (supl. 4).

5. Yusuf S., Hawken S., Ounpuu S. i wsp.; INTERHEART Study Investigators. Effect of potentially modifiable risk factors associated with myocardial infarction in 52 countries (the INTERHEART study): case-control study. Lancet 2004; 364: 937-952.

6. Sundström J., Arima H., Jackson R. i wsp.; Blood Pressure Lowering Treatment Trialists' Collaboration. Effects of blood pressure reduction in mild hypertension: a systematic review and meta-analysis. Ann. Intern. Med. 2015; 162: 184-191.

7. Tykarski A., Narkiewicz K., Gaciąg Z. i wsp. 2015 Guidelines for the management of hypertension. Arterial Hypertens. 2015; 19: 53-83.

8. SPRINT Research Group, Wright J.T. Jr, Williamson J.D., Whelton P.K. i wsp. A randomized trial of intensive versus standard blood-pressure control. N. Engl. J. Med. 2015; 373: 2103-2116.

9. Zdrojewski T., Bandosz P., Szpakowski P. i wsp. Ocena wybranych problemów dotyczących rozpowszechnienia i terapii nadciśnienia tętniczego w Polsce na podstawie badania NATPOL-PLUS. W: Więcek A., Kokot F. (red.). Postępy w nefrologii i nadciśnieniu tętniczym. Tom II. Medycyna Praktyczna, Kraków 2002: 11-15.

10. Bramlage P., Böhm M., Volpe M. i wsp. A global perspective on blood pressure treatment and control in a referred cohort of hypertensive patients. J. Clin. Hypertens. 2010; 12: 666-677.

11. Lloyd-Jones D.M., Evans J.C., Larson M.G. i wsp. Differential control of systolic and diastolic blood pressure: factors associated with lack of blood pressure control in the community. Hypertension 2000; 36: 594-599.

12. Lloyd-Jones D., Evans J., Levy D. Hypertension in adults across the age spectrum: current outcomes and control in the community. JAMA 2005; 294: 466-472.

13. de la Sierra A., Segura J., Banegas J.R. i wsp. Clinical features of 8295 patients with resistant hypertension classified on the basis of ambulatory blood pressure monitoring. Hypertension 2011; 57: 898-902.
14. Garg J.P., Elliott W.J., Folker A. i wsp. Resistant hypertension revisited: a comparison of two university-based cohorts. Am. J. Hypertens. 2005; 18: 619-626.

15. Knight E.L., Bohn R.L., Wang P.S. i wsp. Predictors of uncontrolled hypertension in ambulatory patients. Hypertension 2001; 38: 809-814.

16. Fontil V., Bibbins-Domingo K., Kazi D.S. i wsp. Simulating strategies for improving control of hypertension among patients with usual source of care in the United States: the blood pressure control model. J. Gen. Intern. Med. 2015; 30: 1147-1155.

17. Bakris $\mathrm{G}$. The importance of blood pressure control in the patient with diabetes. Am. J. Med. 2004; 116: 30S-38S.

18. Sur G., Sur M., Kudor-Szabadi L., Sur L. Difficulties in achieving arterial hypertension control. Maedica (Buchar.) 2011; 6: 114-119.

19. Dahlöf B., Sever P., Poulter N. i wsp.; ASCOT Investigators. Prevention of cardiovascular events with an antihypertensive regimen of amlodipine adding perindopril as required versus atenolol adding bendroflumethiazide as required, in the Anglo-Scandinavian Cardiac Outcomes Trial-Blood Pressure Lowering Arm (ASCOT-BPLA): a multicentre randomised controlled trial. Lancet 2005; 366: 895-906.

20. Sica D.A., Hansen K.J., Deitch J.S., Dean R.H. Renovascular disease in blacks: prevalence and result of operative management. Consortium of Southeastern Hypertension Control. Am. J. Med. Sci. 1998; 315: 337-342.

21. Saito I., Kushiro T., Matsushita Y. i wsp. Medication-taking behavior in hypertensive patients with a single-tablet, fixed-dose combination in Japan. Clin. Exp. Hypertens. 2015; 24: 1-6.

22. Angeloni E., Vitaterna A., Lombardo P. i wsp. Single-pill combination therapy in the initial treatment of marked hypertension: a propensitymatched analysis. Clin. Exp. Hypertens. 2015; 37: 404-410.

23. Greenberg R.N. Overview of patient compliance with medication dosing: a literature review. Clin. Ther. 1984; 6: 592-599.

24. Mancia G., Fagard R., Narkiewicz K. i wsp. 2013 Practice guidelines for the management of arterial hypertension of the European Society of Hypertension (ESH) and the European Society of Cardiology (ESC): ESH/ESC Task Force for the Management of Arterial Hypertension. J. Hypertens. 2013; 31: 1925-1938.

25. Tykarski A., Narkiewicz K., Gaciong Z. i wsp. 2015 guidelines for the management of hypertension. Recommendations of the Polish Society of Hypertension - short version. Kardiol. Pol. 2015; 73 : 676-700.

26. Savarese G., Costanzo P., Cleland J.G. i wsp. A meta-analysis reporting effects of angiotensin-converting enzyme inhibitors and angiotensin 
receptor blockers in patients without heart failure. J. Am. Coll. Cardiol. 2013; 61: 131-142.

27. Ceconi C., Francolini G., Olivares A. i wsp. Angiotensin-converting enzyme (ACE) inhibitors have different selectivity for bradykinin binding sites of human somatic ACE. Eur. J. Pharmacol. 2007; 577: $1-6$.

28. Rahman M., Ford C.E., Cutler J.A. i wsp. Long-term renal and cardiovascular outcomes in Antihypertensive and Lipid-Lowering Treatment to Prevent Heart Attack Trial (ALLHAT) participants by baseline estimated GFR. Clin. J. Am. Soc. Nephrol. 2012; 7: 989-1002.

29. Beckett N.S., Peters R., Fletcher A.E. i wsp. Treatment of hypertension in patients 80 years of age or older. N. Engl. J. Med. 2008; 358: 1887-1898.

30. Patel A., MacMahon S., Chalmers J. i wsp. Effects of a fixed combination of perindopril and indapamide on macrovascular and microvascular outcomes in patients with type 2 diabetes mellitus (the ADVANCE trial): a randomised controlled trial. Lancet 2007; 370: 829-840.

31. Zanchetti A., Crepaldi G., Bond M.G. i wsp. Different effects of antihypertensive regimens based on fosinopril or hydrochlorothiazide with or without lipid lowering by pravastatin on progression of asymptomatic carotid atherosclerosis: principal results of PHYLLIS-a randomized double-blind trial. Stroke 2004; 35: 2807-2812.
32. Borhani N.O., Brugger S.B., Byington R.P.; US MIDAS Research Group Multicenter study with isradipine and diuretics against atherosclerosis. J. Cardiovasc. Pharmacol. 1990; 15 (supl. 1): S23-S29.

33. Páll D., Szántó I., Szabó Z. Triple combination therapy in hypertension: the antihypertensive efficacy of treatment with perindopril, amlodipine, and indapamide SR. Clin. Drug Investig. 2014; 34: 701-708.

34. Chalmers J., Arima H., Woodward M. i wsp. Effects of combination of perindopril, indapamide, and calcium channel blockers in patients with type 2 diabetes mellitus results from the Action in Diabetes and Vascular Disease: Preterax and Diamicron Controlled Evaluation (ADVANCE) Trial. Hypertension 2014; 63: 259-264.

35. Tóth K.; PIANIST Investigators. Antihypertensive efficacy of triple combination perindopril/indapamide plus amlodipine in high-risk hypertensives: results of the PIANIST study (Perindopril-Indapamide plus AmlodipiNe in high rISk hyperTensive patients). Am. J. Cardiovasc. Drugs 2014; 14: 137-145.

36. Makani H., Bangalore S., Romero J. i wsp. Effect of renin-angiotensin system blockade on calcium channel blocker-associated peripheral edema. Am. J. Med. 2011; 124: 128-135.

37. Fogari R., Zoppi A., Mugellini A. i wsp. Effect of low-dose manidipine on ambulatory blood pressure in very elderly hypertensives. Cardiovasc. Drugs Ther. 1999; 13: 243-248. 